\title{
EM-Algorithm as a tool for structure analysis of stands of the common reed (Phragmites australis)
}

\author{
Wolfgang Ostendorp \\ Limnologisches Institut, Universität Konstanz, Postfach 5560, W-7750 Konstanz, Germany
}

\author{
and Joachim Möller
}

Fakultät für Wirtschaftswissenschaften und Statistik, Universität Konstanz, Postfach 5560 , W-7750 Konstanz, Germany

\section{ABSTRACT}

Ostendorp, W. and Möller, J., 1991. EM-algorithm as a tool for structure analysis of stands of the common reed (Phragmites australis). Ecol. Modelling, 53: 27-38.

The frequency distributions of morphometric and mechanical properties of randomly sampled stalks of seven reed stands at Lake Constance-Untersee are analysed by the Estimation-Maximisation Algorithm. The aim was to look for composed (bimodal) distribution indicating at least two different stem types. In each stand, between one and nine parameters are found to give a bimodal distribution. The two stem types are 'flowering shoots' and 'non-flowering shoots'. The means of nearly all parameters investigated are different at the $1 \%$ level of significance. The flowerless shoots are identical with 'secondary shoots' and the flowering shoots refer to terminal (= 'primary') shoots. The separation of stem types allows investigation of the stand structure and the influence upon it by 'rhizomeinternal' and 'external' factors in more detail.

\section{INTRODUCTION}

The common reed (Phragmites australis (Cav.) Trin. ex Steud., Poaceae) is a ubiquitous species in central Europe, colonising a wide range of habitats, i.e. lake shores, fenland, brackish tidal marshes and dumping places, provided there is sufficient water in the subsoil. The stature of the reed stalks varies from very short (ca. $0.5 \mathrm{~m}$, on inland saline soils) to very tall culms (ca. $5 \mathrm{~m}$, on fertile sediments of lake shores and estuaries (RodewaldRudescu, 1974). However, even within a stand of limited area one can find a remarkable variability in the performance of the individual stalks. The 
question arises whether the variability within stands can be described by a simple relation to which other parameters can be reduced.

The basis of a comparison of the symmorphology and the structure between different populations is the analysis of frequency distributions of morphological properties. There have been several efforts to use skewness and kurtosis of a distribution of morphometric variables for an ecological interpretation. Ernst (1983, p. 51) postulated that growth parameters of plants will be normally distributed if the plants grow under optimal conditions. If stressed, they would show a negative skewed distribution. Haslam (1970a) investigated the distribution of stalk length in several reed stands. She differentiated 'dominant, dense stands' with a negative skewness and 'restricted sparse stands' with a negative kurtosis. Crook et al. (1983) found in stands which were affected by the 'reed die-back' negative skewed or even bimodal frequency distributions of the stalk length. However, the form of the distribution could change in course of the season. These findings are often based only on the interpretation of histograms and not on statistical tests.

In this paper the hypothesis that, at least, simple parameters such as length, diameter, and number of leaves are normally distributed was re-investigated with improved statistical methods. The suspicion was that values of skewness and kurtosis, reported in previous studies, which differ greatly from those of a normal distribution, do not necessarily contradict this hypothesis but may indicate that the sample chosen was such that two (or more) subpopulations were superimposed, whereby the morphometric properties of each are normally distributed. By means of the $\mathrm{E}$ (xpectation)M(aximisation) Algorithm (Dempster et al., 1977) it is possible to separate different subpopulations according to a maximum-likelihood criterion. Then the hypothesis of a composite distribution is tested against the hypothesis of a simple distribution. If the hyphothesis of a composite distribution if adopted, each sub-distribution is tested for normality. In this way we tried to get some information about the subpopulations, if any exist.

\section{MATERIAL}

This paper analyses the frequency distributions of a total of 18 parameters measured on seven reed stands. The data were collected for other scientific purposes concerning the reed decline and the reed management (Ostendorp, in preparation). The reed stands chosen are monospecific lakeside stands of Phragmites australis (Phragmitetum typicum, sensu Lang, 1967) in Lake Constance, Untersee. The frequency distributions of the following parameters are analysed: 


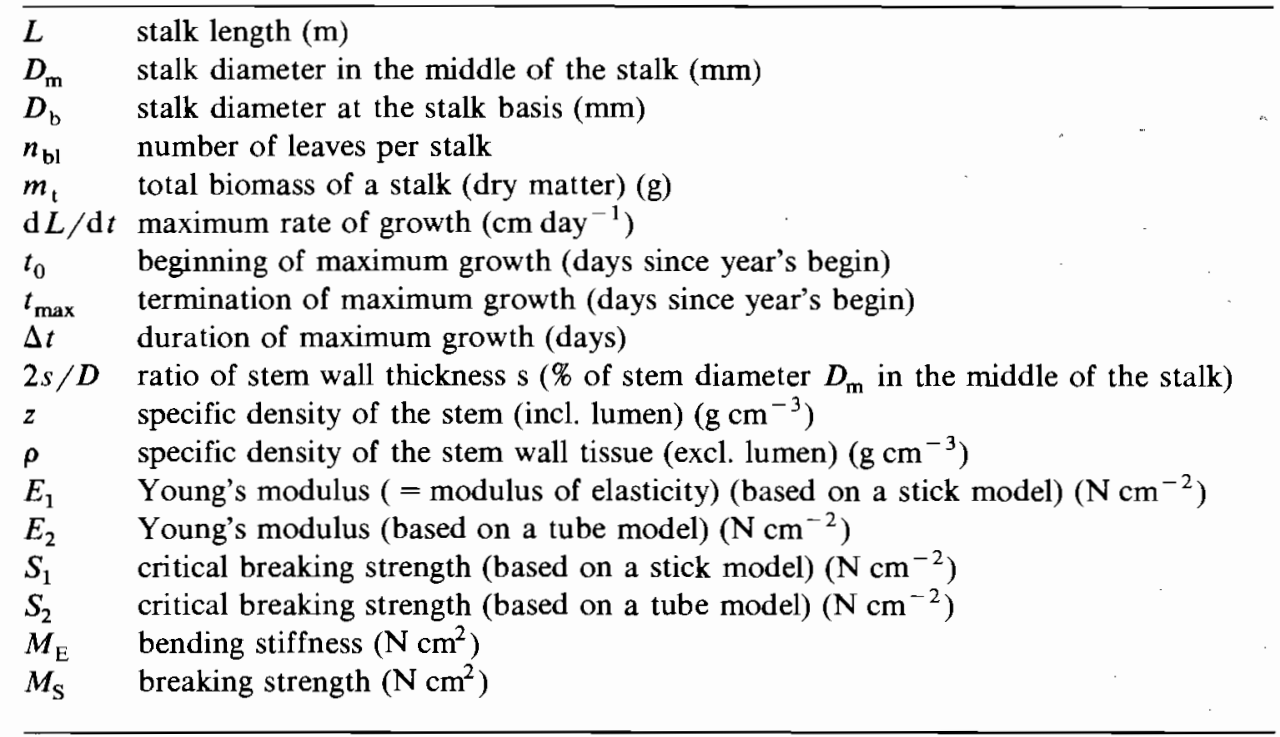

[For definition, measurement and evaluation of these parameters see Ostendorp (1982)]. Only intact stalks are considered here but not stalks with insect galls. Stalks were clipped off at the base, quantitatively or at random, within several test fields of $0.36 \mathrm{~m}^{2}$ each. Measurements were taken in the laboratory. All parameters except $t_{0}, t_{\max }, \Delta t$, and $\mathrm{d} L / \mathrm{d} t$ refer to fully grown stalks.

\section{METHOD}

Let us assume that we have $N$ different observations $x_{i}(i=1,2, \ldots, N)$ for an item. The observations are drawn from $k$ different populations but there is no a priori information about which observation is drawn from which population. The problem is to estimate the moments of the distributions of the observations, the probabilities $p_{i j}$ with which a specific observations $x_{i}$ belongs to population $j$, and the relative size of the populations $\lambda_{j}$ :

$\lambda_{j}=\frac{1}{N} \sum_{i=1}^{N} p_{i j} \quad$ with $\quad \sum_{j=1}^{k} \lambda_{j}=1$

The idea of the EM-Algorithm (Dempster et al., 1977) is to separate this complex problem of estimation into two parts which are easily solvable. In an estimation step the moments of the distributions are estimated under the assumption that the probabilities $p_{i j}$ were known. In a second maximisation step the estimators for $p_{i j}$ are calculated by use of the Bayesian formula for 
conditional probabilities under the assumption that the moments of the distributions are known:

$$
\hat{p}_{i j}=\frac{\lambda_{j} f\left(x_{i} \mid p_{i j}=1\right)}{\sum_{m=1}^{k} \lambda_{m} f\left(x_{i} \mid p_{i m}=1\right)}
$$

where $f(\cdot)$ is the conditional density for $x_{i}$ under a given presumption about the corresponding population and $\sum_{j=1}^{k} \hat{p}_{i j}=1$.

The E- and M-steps are repeated in turn until convergence is achieved. Under the assumption that the observations are independently normally distributed with mean $\bar{x}$ and variance $\sigma^{2}$, the corresponding conditional densities are easily calculated:

$f_{i j}=f\left(x_{i} \mid p_{i j}=1\right)=(2 \pi)^{-1 / 2} \sigma^{-2} \exp \left(-\frac{1}{2} u_{i}^{2} / \sigma^{2}\right)$

where $u_{i}=x_{i}-\bar{x}$. In most cases, convergence was achieved after 50 to 100 iterations.

The method was implemented on a mainframe computer as well as on a IBM-compatible personal computer. A brief description of the program is available on request from the authors.

\section{RESULTS}

The efficiency of the EM-Algorithm can be demonstrated by the frequency distribution of stalk length shown in Fig. 1. The data have been published by Kauppi et al. (1983). The distribution curve is negatively skewed ( $s_{k}=$ $-0.976)$, and the hypothesis of normality of the overall distribution is rejected ( $\chi^{2}$-test: $\left.\alpha<0.001\right)$. Instead of supposing a more complicated distribution, we assumed that the sample taken ( $n=1066$ fully grown stalks) consist of two subpopulations, that is to say $G_{1}$ 'short stalks' and $G_{2}$ 'tall stalks'. A normal distribution is presupposed for each subsample. The EM-Algorithm computes estimates of the means and the variance of $G_{1}$ and $G_{2}$ as well as the share of each subsample. The null hypothesis ("homogeneous population') can be tested by means of a likelihood-ratio test. For the overall sample, the log of the likelihood value gives -374 ; for two different subsamples, the sum of the log likelihood values is +98 . The test statistic is minus two times the difference of the two likelihood values. Thus:

$\hat{\chi}^{2}=-2(-374-98)=944 \gg \chi_{1 ; 0.001}^{2}=10.8$

The null hypothesis can therefore be rejected at the $0.1 \%$ level. The parameters of each frequency distribution are:

$$
\begin{array}{ll}
G_{1}: \bar{x}_{1}=2.16, & \pm s_{x_{1}}=0.35 \\
G_{2}: \bar{x}_{2}=2.60, & \pm s_{x_{2}}=0.14
\end{array}
$$



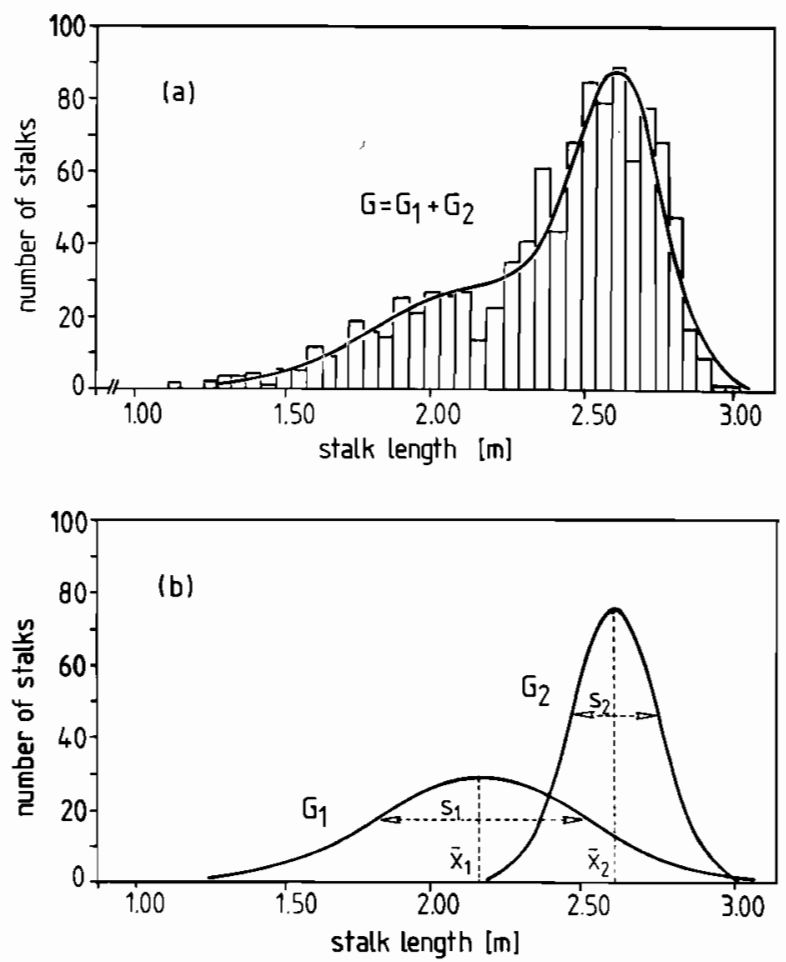

Fig. 1. Application of the EM-Algorithm to the distribution of stalk height in a Finnish reed stand. (a) Histogram: data from Kauppi et al., 1983; solid - computed distribution according to EM-Algorithm. (b) Splitting of the empirical distribution into the sub-distributions $G_{1}$ and $G_{2}$ by the EM-Algorithm.

The two distributions can be superimposed by addition, yielding the computed distribution of the overall sample shown in Fig. 1a. The computed overall distribution fits the original data very well: the null hypothesis (computed distribution $=$ empirical distribution) cannot be rejected even at the $10 \%$ level (nonparametric Kolmogorov-Smirnov test). Hence it can be demonstrated that the reed stand investigated by Kauppi et al. is very likely composed of two different stalk populations.

The results of Lake Constance-Untersee data are given in Table 1: seven reed stands with a total of 18 variables have been analysed by means of the EM-Algorithm. It is clearly demonstrated that, for the most part, a composed frequency distribution can be assumed. This implies the existence of (at least) two different stalk populations within a stand. There is at least one variable in each stand that creates a partition into the two groups. The variables $L$ and $m_{\mathrm{t}}$ are the most appropriate ones for demonstrating the existence of groups. 
TABLE 1

Application of the EM-Algorithm - results

\begin{tabular}{|c|c|c|c|c|}
\hline Stand & $\begin{array}{l}\text { Kind of stress/ } \\
\text { treatment }\end{array}$ & $\begin{array}{l}\text { Sample } \\
\text { size }\end{array}$ & Separating variables & $\begin{array}{l}\text { Non separating } \\
\text { variables }\end{array}$ \\
\hline$\overline{\text { MOD I }}$ & $\begin{array}{l}\text { not seriously } \\
\text { damaged by } \\
\text { mechanical factors }\end{array}$ & 104 & $\begin{array}{l}L^{* * *}, m_{\mathrm{t}}^{* * *}, E_{1}^{* * *} \\
E_{2}^{* * *}, S_{1}^{* * *}, S_{2}^{* * *} \\
M_{\mathrm{E}}^{* * *}, M_{\mathrm{S}}^{* * *}\end{array}$ & $\begin{array}{l}z, \rho, 2 s / D, D_{\mathrm{m}}, \\
n_{\mathrm{b} 1}\end{array}$ \\
\hline MOD II & $\begin{array}{l}\text { mechanically } \\
\text { damaged by } \\
\text { waves and } \\
\text { drifting matter }\end{array}$ & 172 & $D_{\mathrm{m}} * * *$ & - \\
\hline MOD IIIa & $\begin{array}{l}\text { not mechanically } \\
\text { damaged }\end{array}$ & 101 & $L^{* * *}, m_{\mathrm{t}}^{* *}, n_{\mathrm{b} 1}^{* * *}$ & $D_{\mathrm{m}}$ \\
\hline MOD IIIb & $\begin{array}{l}\text { mechanically } \\
\text { damaged by } \\
\text { waves and } \\
\text { drifting matter }\end{array}$ & 113 & $m_{\mathrm{t}} * * *$ & $L, D_{\mathrm{m}}, n_{\mathrm{b} 1}$ \\
\hline $\begin{array}{l}\text { MO XI } \\
40 \mathrm{~m}\end{array}$ & mowed in winter & 160 & $L^{* * *}, D_{\mathrm{m}}^{* * *}$ & - \\
\hline $\begin{array}{l}\text { MO XVII } \\
25 \mathrm{~m}\end{array}$ & mowed in winter & 59 & $\begin{array}{l}L^{* *}, D_{\mathrm{m}}^{* * *}, n_{\mathrm{b} 1}^{* * *} \\
m_{\mathrm{t}}^{* * *}, D_{\mathrm{b}}^{* * *}, \mathrm{~d} L / \mathrm{d} t * * *\end{array}$ & - \\
\hline $\begin{array}{l}\text { MO XVII } \\
35 \mathrm{~m}\end{array}$ & $\begin{array}{l}\text { untreated } \\
\text { reference to } \\
\text { MO XVII } 25 \mathrm{~m}\end{array}$ & 29 & $\begin{array}{l}L^{* * *}, n_{\mathrm{b} 1}^{* * *}, m_{\mathrm{t}}^{* * *}, \\
t_{0}^{* * *}, t_{\max }, \Delta t * * *\end{array}$ & $D_{\mathrm{m}}, \mathrm{D}_{\mathrm{b}}, \mathrm{d} L / \mathrm{d} t$ \\
\hline
\end{tabular}

The reed stands investigated (the denotations used here refer to other publications), each sample size ( $n=$ number of stalks), and the variables for which the algorithm yields a partition or no partition are given; levels of significance at which the null hypothesis (homogenity of the distribution) can be refused (likelihood-ratio test): ${ }^{*}-5 \%,{ }^{*}-1 \%$, $* * *-0.1 \%$

As the data support the view that each stalk population consists of two subpopulations, one may look for a dichotomous variable that simply describes the two subpopulations. During the field work, it was noticed that stalks without a panicle were small and performed weakly with respect to all properties observed compared with panicle-bearing culms. Hence, it was examined whether the variable 'stalk-type' (panicle-bearing vs. non-paniclebearing) could be the variable required.

The arrangement of splitting the population by (1) the EM-Algorithm, and (2) by the variable 'stalk type' was checked as follows: after partition of an empirical distribution by the EM-Algorithm, each individual stalk $i$ shows a distinct probability $p_{i}$ to be an element of the subpopulation 1 and a probability $q_{i}\left(q_{i}=1-p_{i}\right)$ to belong to the subpopulation 2 . Let subpopulation 2 be the one with the greater mean regarding a certain variable. For 
all reed stands and all variables, yielding a partition by the EM-Algorithm, the number of stalks $n$ was computed, for which the following holds:

$p \geq 0.5$ and stalk without panicle: $n_{1}$

$q \geq 0.5$ and stalk with panicle: $n_{2}$

$p<0.5$ and stalk without panicle: $n_{3}$

$q<0.5$ and stalk with panicle: $n_{4}$

If EM-Algorithm and variable 'stalk type' split the population identically, one has to expect that $n_{1}+n_{2}=n_{\text {tot }}$ and $n_{3}+n_{4}=0\left(n_{\text {tot }}\right.$ number of all stalks examined). The value of $\eta$ gives the degree of congruence between the two methods if the partition is not identical:

$\eta=\frac{n_{1}+n_{2}}{n_{\text {tot }}}<1$

The results are given in Table 2. In twelve of the 42 cases the EM-Algorithm failed to give a statistically significant splitting into subpopulations. High degrees of congruence can be achieved for 20 of the remaining 30 cases $(\eta>0.8)$ : the partition by the variable 'stalk type' closely follows the partition created by the EM-Algorithm. Very high $\eta$-values are provided by the variables $L$ and, to a lesser extent, $m_{\mathrm{t}}$. Relatively low $\eta$-values were computed for the growth parameters $\mathrm{d} L / \mathrm{d} t, t_{0}, t_{\max }$ and $\Delta t$. Hence, these variables are less suitable for the description of subpopulations.

The EM-Algorithm can be also used to isolate outliers. The existence of outliers has to be assumed if the splitting into two subpopulations is significant and one subpopulation represents only a small part of the sample (say 1 to 5\%). For the data set analysed here, an identification of outliers and, hence, a partition into 'wrong' subpopulations was found for the variables $E_{1}$ and $E_{2}$ (reed stand MOD I), $m_{\imath}$ (MOD IIIa) and $t_{\max }$ (MO XVII $35 \mathrm{~m}$ ). Yet, the partition could be improved only in the case of $t_{\max }$ by elimination of the outliers.

\section{DISCUSSION}

The morphological characteristics of animal or plant populations are commonly investigated by one of the following three statistical techniques: ordination methods such as principal components, discriminant function analysis, or analysis of variance. These methods require a priori information about the existence of two (or more) subpopulations and the discriminating qualities. This information is, however, not always available [see, for example, the data given by Kauppi et al. (1983)]. In such cases, the procedure suggested here, which is based upon the EM-Algorithm, leads to the desired 
TABLE 2

Degree of congruency $(\eta)$ between splitting by the EM-Algorithm and by the variable 'stalk type', respectively

\begin{tabular}{|c|c|c|c|c|c|c|c|}
\hline & MOD I & MOD II & MOD IIIa & MOD IIIb & $\begin{array}{l}\text { MO XI } \\
40 \mathrm{~m}\end{array}$ & $\begin{array}{l}\text { MO XVII } \\
25 \mathrm{~m}\end{array}$ & $\begin{array}{l}\text { MO XVII } \\
35 \mathrm{~m}\end{array}$ \\
\hline $\begin{array}{l}\text { Stalks } \\
\text { without } \\
\text { panicles }\end{array}$ & $n=35$ & 100 & 17 & 88 & 121 & 37 & 9 \\
\hline $\begin{array}{l}\text { Stalks with } \\
\text { panicles }\end{array}$ & $n=69$ & 72 & 84 & 25 & 39 & 22 & 20 \\
\hline$L$ & $96 \%$ & - & $99 \%$ & $\begin{array}{l}\text { No } \\
\text { partition }\end{array}$ & $99 \%$ & $88 \%$ & $90 \%$ \\
\hline$D_{\mathrm{m}}$ & $\begin{array}{l}\text { No } \\
\text { partition }\end{array}$ & $83 \%$ & $\begin{array}{l}\text { No } \\
\text { partition }\end{array}$ & $\begin{array}{l}\text { No } \\
\text { partition }\end{array}$ & $96 \%$ & $90 \%$ & $\begin{array}{l}\text { No } \\
\text { partition }\end{array}$ \\
\hline$D_{\mathrm{b}}$ & - & - & - & - & - & $90 \%$ & $\begin{array}{l}\text { No } \\
\text { partition }\end{array}$ \\
\hline$n_{\mathrm{b} 1}$ & $\begin{array}{l}\text { No } \\
\text { partition }\end{array}$ & - & $92 \%$ & $\begin{array}{l}\text { No } \\
\text { partition }\end{array}$ & - & $81 \%$ & $76 \%$ \\
\hline$m_{\mathrm{t}}$ & $95 \%$ & - & $22 \%$ & $96 \%$ & - & $80 \%$ & $86 \%$ \\
\hline$E_{1}$ & $36 \%$ & - & - & - & - & - & - \\
\hline$E_{2}$ & $36 \%$ & - & - & - & - & - & - \\
\hline$S_{1}$ & $85 \%$ & - & - & - & - & - & - \\
\hline$S_{2}$ & $82 \%$ & - & - & - & - & - & - \\
\hline$M_{\mathrm{E}}$ & $92 \%$ & - & - & - & - & - & - \\
\hline$M_{\mathrm{S}}$ & $93 \%$ & - & - & - & - & - & - \\
\hline $\mathrm{d} L / \mathrm{d} t$ & - & - & - & - & - & $59 \%$ & $\begin{array}{l}\text { No } \\
\text { partition }\end{array}$ \\
\hline$t_{0}$ & - & - & - & - & - & $75 \%$ & $79 \%$ \\
\hline$t_{\max }$ & - & - & - & - & - & $68 \%$ & $61 \%$ \\
\hline$\Delta t$ & - & - & - & - & - & $75 \%$ & $90 \%$ \\
\hline
\end{tabular}

The variables $z, \rho$ and $2 s / D$ are omitted because no partition could be found; the $\eta$ values have been computed without regard of outliers, except in $t_{\max } /$ MO XVII $35 \mathrm{~m}$ when one outlier has been eliminated; the number of measured stalks is given.

results. This method makes full use of the shape of the empirical distribution and does not require any additional information. Furthermore, the variances can be different in the two (or more) subpopulations. The EM-Algorithm as a tool for exploring distributions which are composed of a number of superimposed normal distributions is used here in a univariate context; generalisation to the multivariate case is possible.

Statistical analysis of the literature and our own measurements have demonstrated that even monospecific plant populations of simple architecture like Phragmites stands consist of two (or more) subpopulations represented by different stalk types. The EM-Algorithm led to a highly significant 


\section{TABLE 3}

Differences between the stalk classes 'panicle-bearing-shoots' and 'non-panicle-bearing shoots'

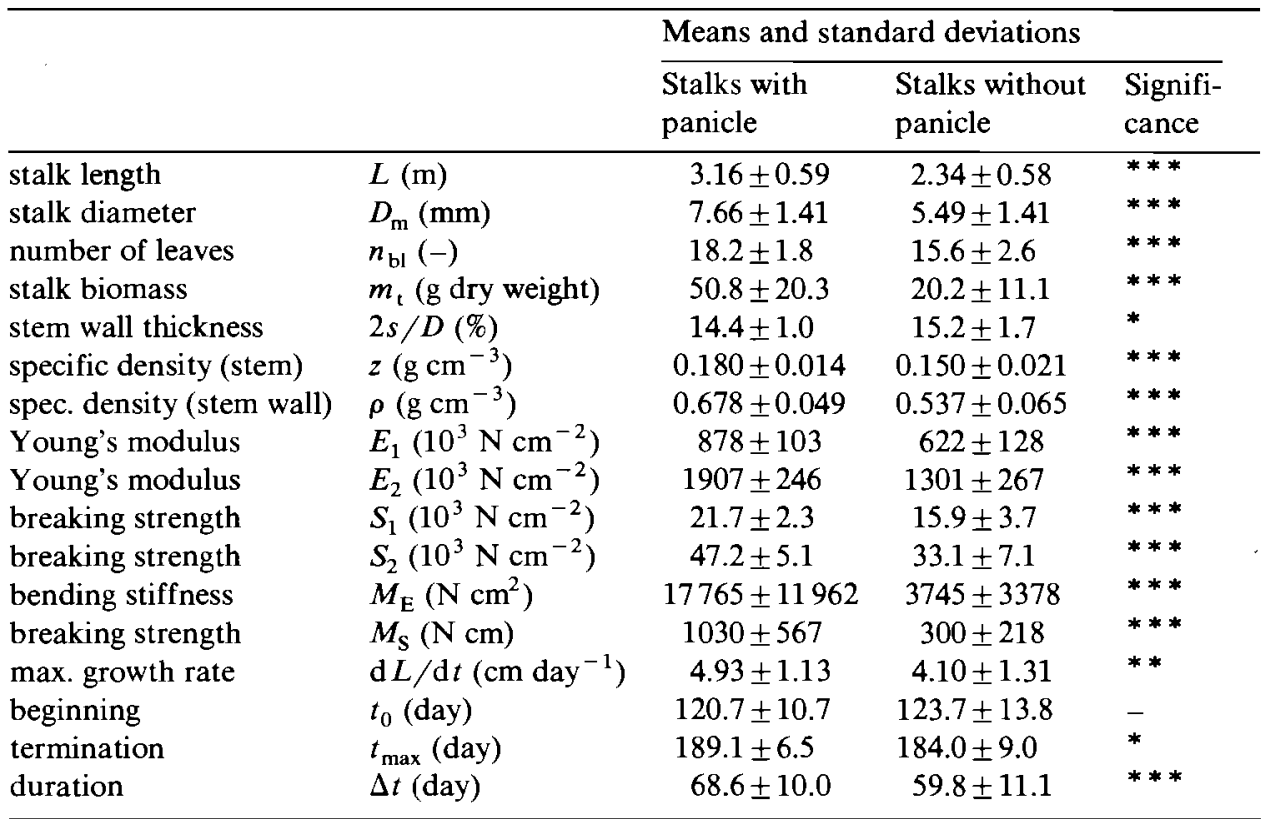

Global means $\pm \mathrm{sd} ; n=13$ to 204 reed stands; levels of significance, see Table 1

partition for a great variety of variables. The two subpopulations can be simply characterised as 'stalks with a panicle' and 'stalks without a panicle'. The performance of the non-panicle-bearing shoots is consistently weaker compared to the panicle-bearing shoots (Table 3); only the wall of the stem is slightly thicker (variable $2 s / D$ ). Furthermore, the proportions of stalks are significantly different: the $L / D_{\mathrm{m}}$-ratio is lower for flowerless shoots, but the ratio 'biomass of leaves/total biomass of the shoot' is higher ( 0.27 vs. 0.22 , Ostendorp, unpublished data). Haslam (1970b) found the number of nodes to be lower in non-panicle-bearing culms. Krolikowska (1971) showed that the transpiration of this stalk type was the $1 \frac{1}{2}$-fold of the flowering shoots. The stem tissue of flowerless stalks contains more ash, nitrogen and phosphorus (Mochnacka-Lawacz, 1974).

The consistent differences regarding a great set of properties justifies looking at the subpopulations as two distinct stalk classes. This implies the need to discuss their (different) origins. As in many cases the diameter at the stem basis is different, it is postulated that the properties 'panicle-bearing' and 'non-panicle-bearing' is controlled by the rhizomes (Ostendorp, in preparation). 
The stalks which had been subjected to insect attack (e.g. Lipara sp., Diptera, Chloropidae; Archanara geminipunctata, Lepidoptera, Noctuidae) form a third class. But, in contrast to the first two classes, the shortened stem axis and the lowered stem diameter are subsequent effects of the insect infestation. If the stalks had not been infested, they would have developed into either flowering or non-flowering shoots, belonging to one of the first two classes. By means of the $D_{\mathrm{b}}$-distribution in each class, one can estimate the possibility that an infested stalk with a known $D_{\mathrm{b}}$ can be fitted in one of them. In the reed stand MO XVII $25 \mathrm{~m}$ (15 stalks damaged by Lipara sp.), 13 stalks fell into the group $G_{1}$ (weak stalks) and only two belonged to $G_{2}$ (stout stalks). In contrast, in the adjacent stand MO XVII $35 \mathrm{~m} \mathrm{(23} \mathrm{stalks}$ damaged by Archanara geminipunctata), five stalks were of the $G_{1}$-type and 18 of the $G_{2}$-type. In this latter stand, the $G_{1}$-type stalks were infested more than average, and in the former stand they were damaged less than average. The ecological behaviour of each of the two insect species is assumed to be the cause of the differential infestation ratio (Vogel, 1984).

The ratio of $G_{1}$-type to $G_{2}$-type culms is different for different reed stands. High values occur particularly in winter-mowed or burned reeds [on average, 18.1 to 22.7 stalks $\mathrm{m}^{-2}$ (Ostendorp, unpublished data)] and in stands which suffered from waves and drifting matter (cf. MOD IIIb in Tables 1 and 2); in stands without mechanical damage the ratio drops below 0.1 . It is postulated that the enhanced occurrence of $G_{1}$-type stalks is controlled by the damage to the apical meristems by mowing, burning, grazing, drifting matter, and frost. Hence, the $G_{1}$ class seems to be identical with the 'secondary (= lateral) shoots' [sensu Haslam $(1969,1970 \mathrm{a}, \mathrm{b})$ ] that compensate the 'primary (= terminal) shoots' which had died off. Whether this overlap is quantitative needs to be demonstrated by subsequent research.

\section{SUMMARY}

The subject of the paper was to investigate the hypothesis that the morphometric properties of a stalk population of the common reed (Phragmites australis) are normally distributed. In contrast to previous studies the possibility that a random sample could be composed of two or more subsamples belonging to different subpopulations was explicitely taken into account. It can be demonstrated that neglecting the possibility of superimposed distributions can result in an erroneous rejection of the normality hypothesis. The statistical procedure used here is based on the Expectation-Maximisation Algorithm. This method exploits the shape of the empirical distribution and does not require a priori information about the discriminating properties of the subpopulation. 
The algorithm computed the means and variances of each subpopulation and a likelihood-ratio test was used to test the hypothesis of heterogenity against the null hypothesis of homogenity of the sample. In 30 of a total of 42 cases the homogeneity assumption was rejected. Hence, it was concluded that most of the lakeside reed stands at Lake Constance consist of at least two different shoot populations. The culm types could be characterised as panicle-bearing or flowering shoots and non-flowering shoots without a panicle. Non-flowering shoots were the weaker ones in all respects. It was assumed that the discrimination against the non-flowering shoots is controlled by the rhizome. The proportion of this class of shoots was high in stands which had been previously damaged by frost, waves, drifting matter, waterfowl grazing etc.; this indicated that flowerless shoots are identical with 'secondary' (= lateral) shoots which recover 'primary' (= terminal) shoots lost by mechanical damage. The separation of (at least) two stem types allows a more detailed investigation of the stand structure of reed and the influence upon it by 'rhizome-internal' and 'external' factors.

\section{ZUSAMMENFASSUNG}

In der vorliegenden Untersuchung wurde die Hypothese der Normalverteilung ausgewählter morphometrischer Eigenschaften einer Halmpopulation des Schilfs (Phragmites australis) überprüft. Im Gegensatz zu anderen Studien wurde die Möglichkeit explizit in Betracht gezogen, daß eine $\mathrm{Zu}$ fallsstichprobe aus mehreren Unterstichproben zusammengesetzt sein könnte, die jeweils aus unterschiedlichen Grundgesamtheiten stammen. Es konnte gezeigt werden, daß die Vernachlässigung dieser Möglichkeit zu einer irrtümlichen Zurückweisung der Normalitätsannahme führen kann. Das hier benutzte statistische Verfahren stützt sich auf den 'Expectation-Maximisation-Algorithmus'; es wertet allein die Form der empirischen Häufigkeitsverteilung aus und bedarf keiner a priori Information über die diskriminierenden Eigenschaften etwaiger Subpopulationen.

Der Algorithmus berechnet die Mittelwerte und Varianzen von Merkmalen einer jeden Subpopulation. Mit einem Likelihood-Ratio-Test wurde die Alternativhypothese (Heterogenität) gegen die Nullhypothese (homogene Verteilung) geprüft. In 30 von 42 Fällen konnte eine signifikante Trennung erzielt werden, so dass anzunehmen ist, dass sich die meisten Schilfbestände aus (mindestens) zwei verschiedenen Halmpopulationen zusammensetzen. Die beiden Halmgruppen lassen sich als 'rispentragende Halme' und 'rispenlose Halme' beschreiben. Die rispenlosen Halme sind in fast allen untersuchten Eigenschaften schwächer ausgebildet als die rispentragenden Halme des gleichen Bestandes. Vermutlich wird die Benachteiligung ihrer Wuchsleistung durch das Schilfrhizom gesteuert. Besonders hoch ist ihr 
Anteil in mechanisch belasteten Beständen; dabei ist die Klasse 'rispenlose Halme' weitgehend identisch mit den 'Sekundärtrieben' (= Lateraltriebe), die die durch mechanische Schädigung, Frost, Wellenschlag, Treibgut und Beweidung verloren gegangenen 'Primärtriebe' (Terminalsprosse) ersetzen. Die Unterscheidung von (mindestens) zwei verschiedenen Halmtypen erlaubt eine detailliertere Untersuchung der Bestandsstruktur von Schilfröhrichten und ihrer Beeinflussung durch 'rhizom-interne' und 'externe' Faktoren.

\section{ACKNOWLEDGEMENT}

We are grateful to Dr. W. Nagl, Universität Konstanz for helpful comments.

\section{REFERENCES}

Crook, C.E., Boar, R.R. and Moss, B., 1983. The decline of reedswamps in the Norfolk Broadlands: Causes, consequences and solution. Broads Authority Ser. 6: 1-132, Norwich.

Dempster, A.P., Laird, N.M. and Rubin, D.B., 1977. Maximum Likelihood from incomplete data via the EM-Algorithm. J. R. Stat. Soc., 39: 1-38.

Ernst, W.H.O., 1983. Ökologische Anpassungsstrategien an Bodenfaktoren. Ber. Dtsch. Bot. Ges., 96: 49-71.

Haslam, S.M., 1969. Stem types of Phragmites communis. Ann. Bot., 33: 127-131.

Haslam, S.M., 1970a. Variation of population type in Phragmites communis. Ann. Bot., 34: $147-158$.

Haslam, S.M., 1970b. The development of the annual population in Phragmites communis. Ann. Bot., 34: 572-591.

Kauppi, P., Selkäinaho, J. and Puttonen, P., 1983. A method for estimating aboveground biomass in Phragmites stands. Ann. Bot. Fenn., 20: 51-55.

Krolikowska, J., 1971. Transpiration of reed (Phragmites communis TRIN.). Pol. Arch. Hydrobiol., 18: 347-358.

Lang, G., 1967. Die Ufervegetation des westlichen Bodensees. Arch. Hydrobiol. Suppl., 32: 437-574.

Mochnacka-Lawacz, H., 1974. The effect of mowing on the dynamics of quantity biomass and mineral content of reed (Phragmites communis Trin.). Pol. Arch. Hydrobiol., 21: 381-386.

Ostendorp, W., 1982. Konstanzer Methoden der Röhrichtforschung. Report of Limnologisches Institut, Univ. Konstanz, 75 pp.

Ostendorp, W., in preparation. Stand structure and shoot density regulation in Phragmites australis stands in Lake Constance-Untersee.

Rodewald-Rudescu, L., 1974. Das Schilfrohr. Die Binnengewässer, 27. Stuttgart, VI + 302 pp. Vogel, M., 1984. Ökologische Untersuchungen in einem Phragmites-Bestand. Ber. Akad. Natursch. Landschaftspfl., 8: 130-166. Laufen/Salzach (FRG). 